\title{
BIOLOGICAL, SEROLOGICAL AND MOLECULAR DETECTION OF TOMATO MOSAIC VIRUS INFECTING PEPPER PLANTS FROM TURKEY
}

\author{
ÇULAL-KILIÇ, H. \\ Department of Plant Protection, Faculty of Agricultural Sciences and Technologies, Isparta \\ Applied Sciences University, Isparta, Turkey \\ (e-mail: handankilic@isparta.edu.tr) \\ (Received $3^{\text {rd }}$ Jan 2019; accepted $27^{\text {th }}$ Feb 2019)
}

\begin{abstract}
This study was carried out to detect the presence Tomato mosaic virus (ToMV) by biological, serologic and molecular methods in the pepper production areas in Burdur and Denizli provinces. Symptoms related with virus infections on the pepper plants were observed during the surveys. Mechanical inoculation studies, DAS-ELISA (Double-antibody sandwich enzyme linked immunosorbent assay) tests, IC-RT-PCR (Immunocapture Reverse transcription polimerase chain reaction) studies were carried out during the work carried out to define the virus. The plants collected from the field that were suspicious with regards to being infected with the virus were first tested by the ELISA method. It was determined that 10 of the 209 tested samples were infected with ToMV. The samples that gave positive results during ELISA tests were used in the mechanical inoculation studies. Symptoms were observed in the indicator plants within a period of 7-10 days. 20 plant samples that gave negative ToMV values in the ELISA tests but had absorbance values close to positive along with the 10 samples that were tested as positive in the DAS-ELISA were used in the IC-RT- PCR method. All of the 30 samples produced expected amplification size of band with $318 \mathrm{bp}$ as observed on agarose gel electrophoresis.
\end{abstract}

Keywords: vegetables viruses, identification, DAS-ELISA, IC-RT-PCR

\section{Introduction}

Pepper (Capsicum annum L.) is a member of the Solanaceae family and is a hot and mild climate plant. The homeland of pepper is stated to be tropical South America and especially Brazil. Pepper was brought England from Spain in the 1500s from where it spread to the rest of Europe. China is the leader in worldwide pepper production as of 2016 with 13.189 .303 tons. It is followed by Mexico with 2.335.560 tons whereas Turkey is ranked three with 1.986 .700 tons. Turkey is followed by Indonesia and USA (TUIK, 2016; FAO, 2016).

Pepper is rich in vitamins A and C. Peppers can be used as fresh or as canned, in pastes, as pickled, in concentrated tomato soups, ready soups, in making powdered or chili peppers, in paint industry, pharmaceutical industry etc. (Anonymous, 2017).

Burdur and Denizli are important in vegetable production due to their soil and climate properties as well as irrigation options. Especially Kale district of Denizli cultivates good quality peppers.

Significant efficiency losses occur in pepper cultivation due to wrong or insufficient agricultural applications as well as biotic and abiotic disease factors. There are many fungi, bacteria and virus based diseases in the vegetable cultivation areas which limit cultivation. Virus diseases are significant among these factors due to their chemical and physical structures, sizes, types of infection, symptom formation, transport and the lack of an effective struggle against them (Agrios, 1997).

Kenyon et al. (2014) have stated that there are about 68 viruses that cause diseases in peppers. The viruses that are observed in pepper which cause significant losses in 
efficiency are as follows: Tobacco mosaic virus (TMV), Tomato mosaic virus (ToMV), Cucumber mosaic virus (CMV), Potato Y virus (PVY), Tomato spotted wilt virus (TSWV), Alfalfa mosaic virus (AMV), Pepper mild mottle (PMMoV), Pepper veinal mottle virus (PVMV), Pepper ringspot virus (PRSV) (Ryu et al., 2009; Arogundade et al., 2012).

ToMV belongs to the Tobamovirus type. Virus includes linear single helical RNA genome. It has a rod shaped particle structure. The virus has a length of about $300 \mathrm{~nm}$ and a width of about $18 \mathrm{~nm}$. Virus particles consist of 5\% nucleic acid; 95\% protein. The genome is single pieced. ToMV can be spread between plants on workers' hands, tools and clothes with normal activities such as plant tying, harvest. Seed can be infected and pass the virus to the plant. Tomato mosaic virus can survive in infected root debris in the soil for up to two years (Silva et al., 2011).

TMV, ToMV, CMV, PMMoV, TSWV, PVY, AMV have been determined during the studies carried out related with the diseases of peppers in our country (Şevik, 2011; Sertkaya, 2012; Özdağ and Sertkaya, 2017; Geyik, 2017).

The existence of virus diseases, their harms and their symptoms vary in accordance with the type of the pepper plant as well as the environmental conditions. That is why, first the detection of the viruses in the culture plant that is cultivated should be made in order to minimize the damages caused by virus disease and to develop control methods. It is not correct to carry out diagnosis based only on observation for virus detection. In recent years, PCR methods have been developed in parallel with molecular techniques which enable sensitive and accurate diagnosis of pepper viruses from plant tissues (Jacobi et al., 1998; Vinayarani et al., 2011; Kumar et al., 2011; Gümüş and Paylan, 2013).

The aim of this study is to determine ToMV in the pepper production areas of Burdur and Denizli provinces by DAS-ELISA, mechanical inoculation and IC-RT-PCR method.

\section{Materials and methods}

\section{Plant material}

The main material of this study consists of 209 leaf samples (115 samples from Denizli +84 samples from Burdur) which show virus disease symptoms and which are thought to be infected with virus. The samples were collected from the pepper production areas (8 locations) during June-September in 2012-2013. The samplings were made from plants with leaf deformation, leaf curling, necrosis formation on the leaves, mosaic symptoms and stunting symptoms. There is no difference between sampling sites during surveys. The samples were labeled inside polyethylene bags and brought to the laboratory in ice boxes to be preserved in deep freezer $\left(-20^{\circ} \mathrm{C}\right)$ until the required tests were carried out.

\section{Serological test method (DAS-ELISA)}

ToMV-DAS-ELISA (BIOREBA AG, Switzerland) commercial kit was used in the study. The application were performed were performed as described by Clark and Adams (1977).

Accordingly, $200 \mu \mathrm{l}$ of IgG was added to each of the hole of ELISA plate, which was diluted in the coating buffer at a ratio of 1:1000 which was then kept at $+4{ }^{\circ} \mathrm{C}$ for 
overnight. Afterwards the ELISA plates were washed with the washing buffer. The washing was repeated 3 times. The plant extracts prepared by diluting at a ratio of $1 / 10$ using extraction buffer was added to each hole as $200 \mu \mathrm{l}$ and was kept overnight at $+4{ }^{\circ} \mathrm{C}$. Washing was repeated the next day. After washing process, conjugated antibody was diluted at a ratio of 1:1000 in the conjugate buffer, $200 \mu 1$ was added to each hole and was kept at $37^{\circ} \mathrm{C}$ for $4 \mathrm{~h}$. After the washing process, each substrate prepared as $1 \mathrm{mg} / \mathrm{ml}$ in the substrate solution was added to each hole as $200 \mu \mathrm{l}$ and was left to wait at room temperature. Finally, p-nitrophenyl phosphate in diethanolamine substrate buffer; (pH: 9.8) was added and $405 \mathrm{~nm}$ values were measured at a microplate reader VersaMax microplate reader (Molecular Devices, Sunnyvale, CA) after 60-120 min. Samples with absorbance values greater than twice the mean absorbance reading of healthy controls obtained from (Bioreba, Switzerland) were considered positive for ToMV (Şevik, 2016).

\section{Mechanical inoculation studies}

Mechanical inoculation was carried out on test plants during the 3-4 leaf stage using the samples that yielded positive reaction as a result of the ELISA tests of ToMV infection suspicious leaf samples collected during the survey. To this end, plant tissues acquired from ToMV infested plants were prepared at a ratio of $1: 1(\mathrm{~W} / \mathrm{V})$ in $0.01 \mathrm{M}$ phosphate buffer solution $(\mathrm{pH} ; 7.2)$ including $0.01 \%$ 'lik 2-Mercaptoethanol and was inoculated to the leaves of the test plants. Capsicum annuum, Chenopodium amaranticolor, Nicotiana glutinosa, Nicotiana tabacum L. "Xanthii", Nicotiana tabacum "White Burley" were used as test plants (Aghamohammadi et al., 2013). Plant growth cabins at $18-20{ }^{\circ} \mathrm{C}$ temperature were used to observe symptoms in test plants. Mechanical inoculation studies were repeated until symptoms were seen.

\section{Molecular test method (IC-RT-PCR)}

Immunocapture-RT-PCR method was used as molecular test method since it is more advantageous due to the direct usage of plant extracts after mixing with water without any need for nucleic acid isolation. Antibodies specific to the virus were used, viral forms in the crushed plant material were captured immunologically and were used in viral RNA amplification. The DAS-ELISA positive samples (10 samples) and the samples with absorbance values close to positive (20 samples) were used in molecular studies for a total of 30 samples. In the Immunocapture-RT-PCR method:

- PCR tubes were coated with the antibody specific to the virus during ELISA studies and were left for incubation at $4^{\circ} \mathrm{C}$ for the overnight.

- Tubes were washed with PBS-Tween Buffer for 3 times after incubation and they were left to wait in the deep freezer until molecular studies.

- During molecular studies.

- plant tissue extract, as prepared above for ELISA, was loaded into the antibody-coated tubes and incubated. The samples were left for incubation at $+4{ }^{\circ} \mathrm{C}$ overnight.

- Tubes were washed with PBS-Tween Buffer for 3 times after incubation and were also washed once with sterile pure water.

- RT-PCR mixture was added to these PCR tubes afterwards. 
RT-PCR was performed using a One Step RT-PCR Kit (Bio Basic, Canada Inc). Reverse transcription was performed in a $50 \mu \mathrm{l}$ reaction mixture containing, $21 \mu \mathrm{l} \mathrm{H}{ }_{2} \mathrm{O}$, $25 \mu \mathrm{l} 2 \times 1$ PrimeScript One Step RT-PCR buffer (containing dNTP mixture, One step Enhancer solution), $2 \mu$ Prime Script 1 step enzyme mix, $1 \mu 120 \mathrm{Mm}$ primers. RT-PCR of ToMV replicase gene portion of approximately $318 \mathrm{bp}$ were amplified.

An approximately $318 \mathrm{bp}$ DNA fragment was amplified from ToMV-infected plants by IC-RT-PCR with a ToMV specific primer pairs. Oligonucleotide primer sequences were used to detect ToMV reported by Kumar et al. (2011):

F-5-CGAGAGGGGCAACAAACAT-3

R-5-ACCTGTCTCCATCTCTTTGG-3

Thermocycling (Techne-TC-5000) was programmed as 1 cycle at $50{ }^{\circ} \mathrm{C}$ for $30 \mathrm{~min}$, at $94{ }^{\circ} \mathrm{C}$ for $2 \mathrm{~min}$ and 40 cycles at $94{ }^{\circ} \mathrm{C}$ for $30 \mathrm{~s}$, at $54{ }^{\circ} \mathrm{C}$ for $30 \mathrm{~s}$, at $72{ }^{\circ} \mathrm{C}$ for $30 \mathrm{~s}$ and finally at $72{ }^{\circ} \mathrm{C}$ for $1 \mathrm{~min}$.

Pepper plant leaves infected with ToMV in DAS-ELISA studies and ToMV-infected C. amaranticolor and Capsicum annuum plant leaves were used as positive control in molecular studies; whereas healthy pepper plant leaves were used as negative control.

IC-RT-PCR products were separated on a $1 \%$ agarose gel by electrophoresis (Bio$\mathrm{Rad}$ ) and stained in a $0.5 \mu \mathrm{g} / \mathrm{ml}$ ethidium bromide solution. An image was captured after the exposure of ethidium-bromide-stained gel on a transilluminator with a digital camera (UVP-Doc-It). 100 bp DNA ladder (Thermoscientific, GeneRuler) was used as marker.

\section{Results}

Symptoms such as leaf deformation, leaf curling, decoloring of the leaves, necrosis formation on the leaves, mosaic symptoms and stunting symptoms have been observed and these plants have been photographed during the survey (Fig. 1).

Firstly, ELISA tests were carried out on the leaf samples collected from 209 plants with virus infection symptoms in order to determine the existence of ToMV. The results showed that 10 out 209 samples were infected with ToMV. Whereas ToMV infection rate for 209 of the collected samples was determined as $4.78 \%$.

Mechanical inoculation studies were carried out using ToMV infected leaves that were detected after ELISA tests. Chlorotic local lesion symptoms were observed in Chenopodium amaranticolor of the plants one week after inoculation; whereas local lesion symptoms were observed at Nicotiana glutinosa 10 days after inoculation and the symptoms have been photographed (Figs. 2 and 3). On the other hand, Capsicum annиum directly developed systemic symptoms as mosaic, stunding (Cherian and Muniyappa, 1998; Aghamohammadi et al., 2013; Ullah et al., 2017) (Fig. 4). The presence of ToMV was further confirmed through mechanical inoculation and IC-RTPCR.

IC-RT-PCR method is one of the molecular methods that is widely used in many studies to detect virus diseases in plants and this was used on pepper samples to detected the ToMV. 10 samples yielded positive results as a result of the testing of the 209 leaf samples collected from the pepper cultivation area by DAS-ELISA. At this stage of the study, 20 isolates which yielded negative results in the DAS-ELISA tests but which had absorbance values close to positive along with 10 samples that yielded positive results in DAS-ELISA were used in the IC-RT-PCR studies which is more sensitive in comparison to ELISA. It was determined a result of the RT-PCR works on 
plant samples that all of the samples yielded the expected band specific to ToMV (318 bp) and that all of the 30 samples $(100 \%)$ were infected with ToMV. No fragment was amplified from negative control (Figs. 5, 6 and 7).

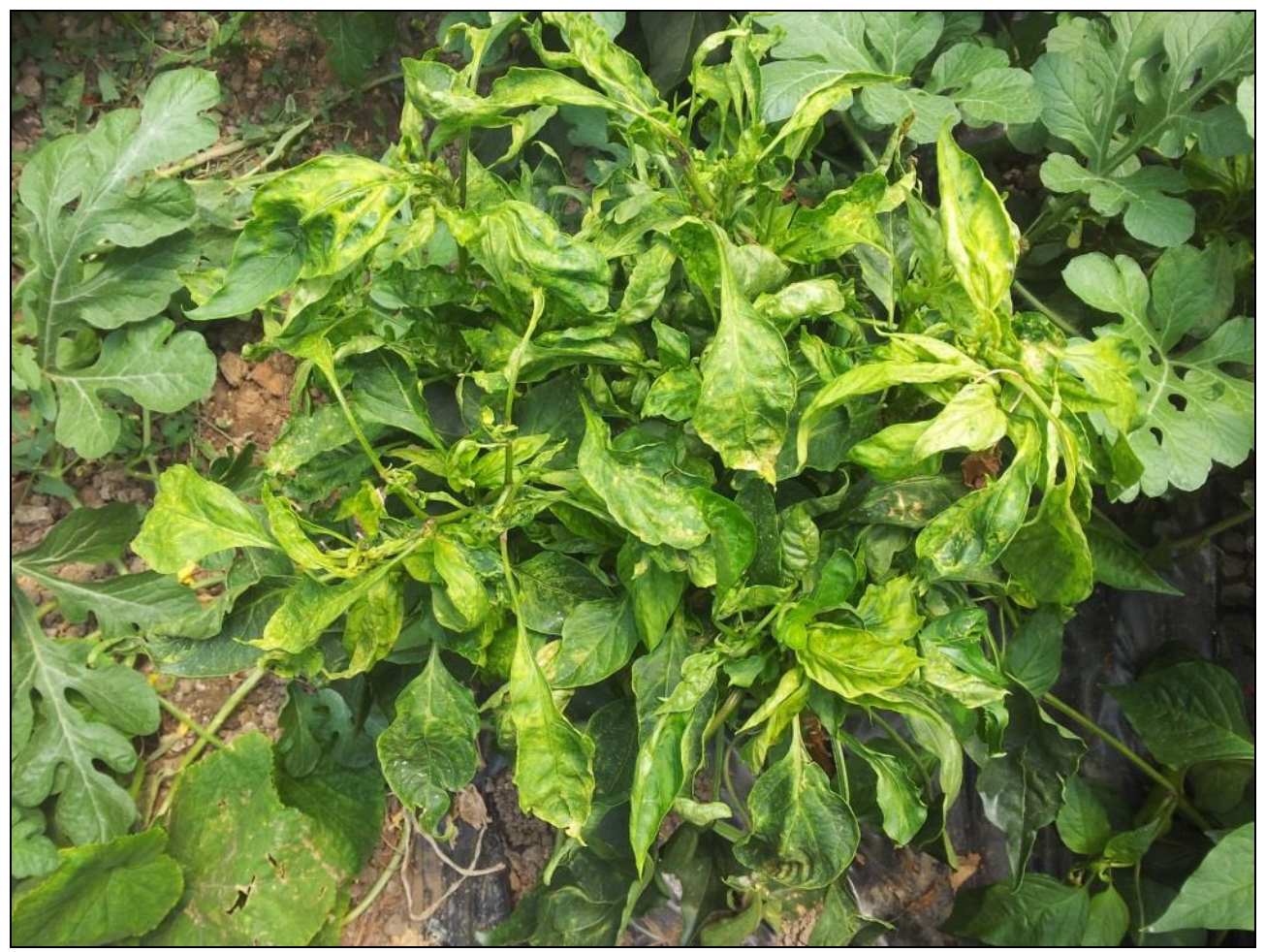

Figure 1. Mosaic and deformation symptoms observed in pepper leaves

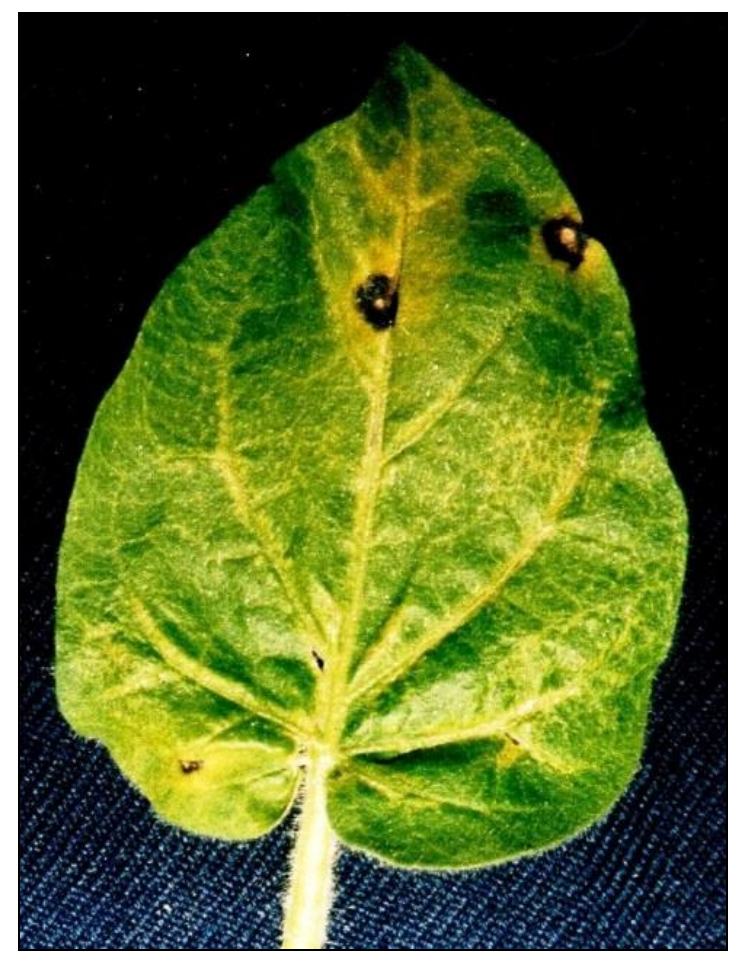

Figure 2. Necrotic local lesion on Nicotiana glutinosa 


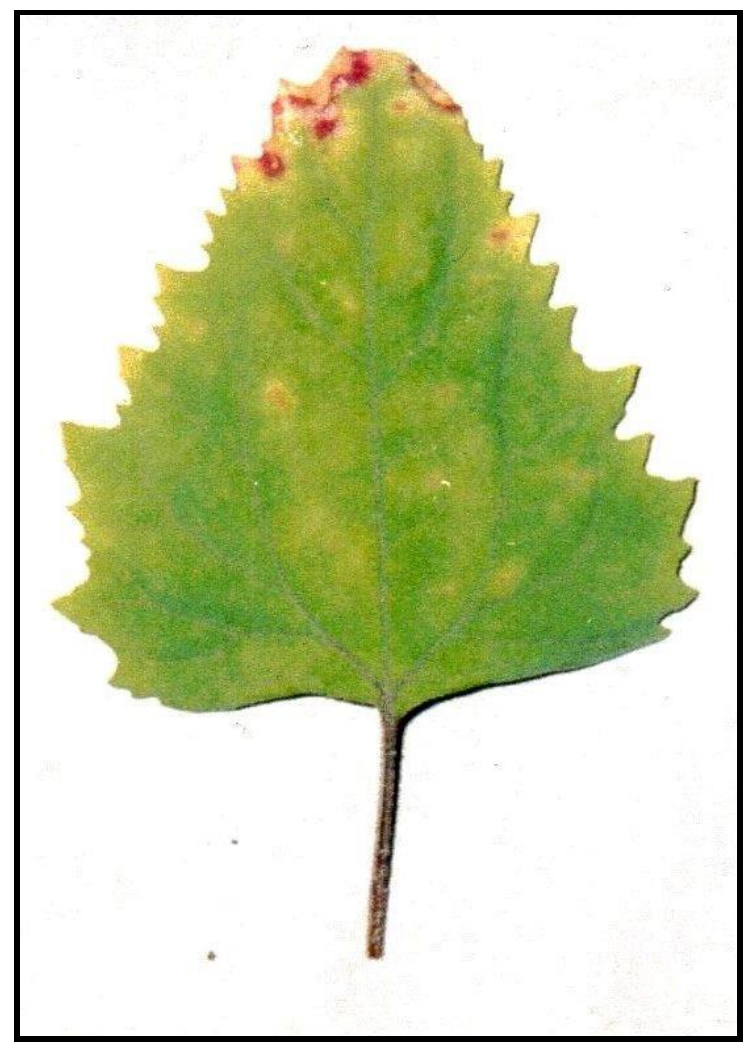

Figure 3. Chlorotic local lesion on Chenopodium amaranticolor

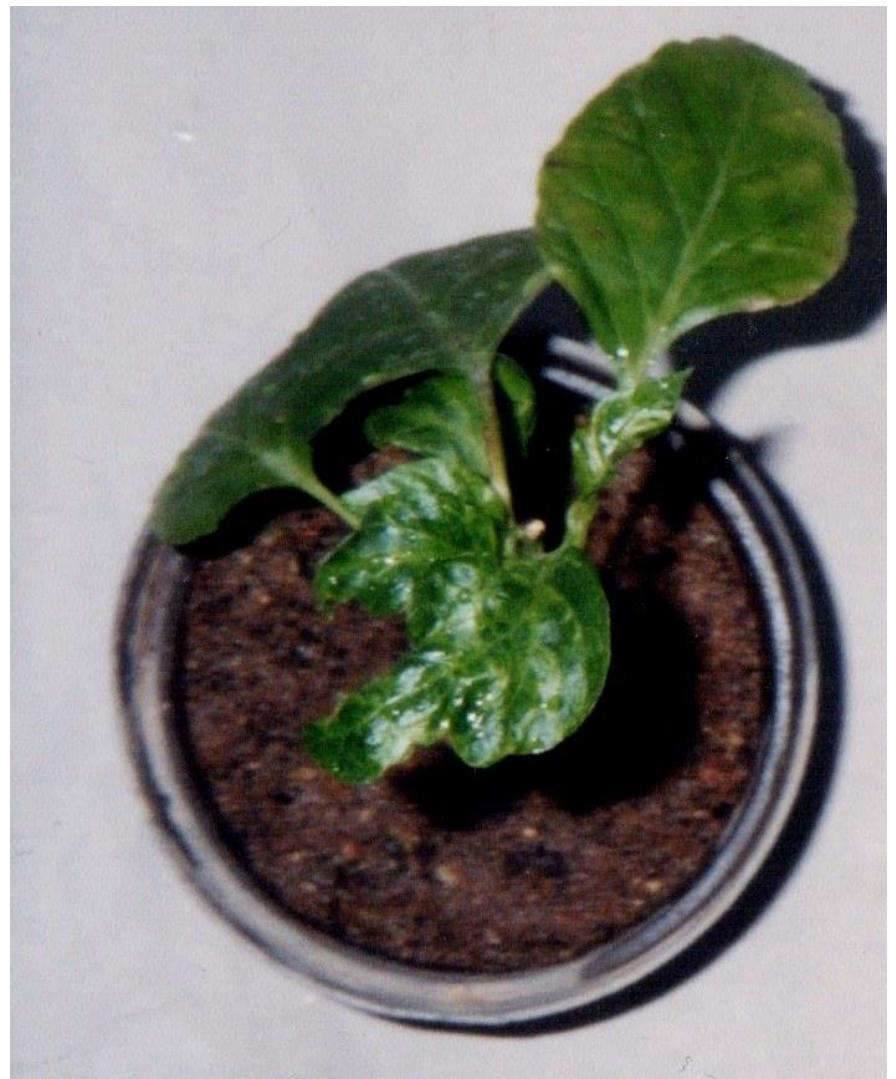

Figure 4. Mosaic and deformation on Capsicum annuиm

APPLIED ECOLOGY AND ENVIRONMENTAL RESEARCH 17(3): 6337-6347. http://www.aloki.hu • ISSN 15891623 (Print) • ISSN 17850037 (Online) DOI: http://dx.doi.org/10.15666/aeer/1703_63376347 (C) 2019, ALÖKI Kft., Budapest, Hungary 


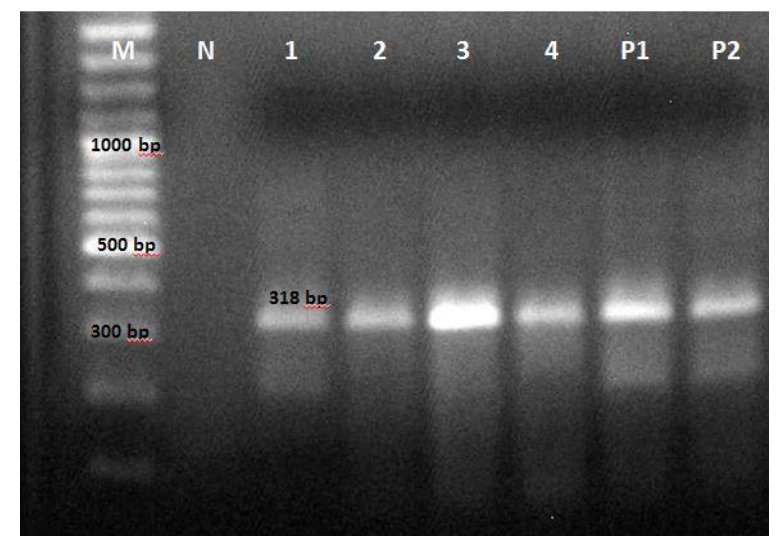

Figure 5. Detection of Tomato mosaic virus by IC-RT-PCR. M: $100 \mathrm{bp}$ DNA ladder; N: healthy pepper. Lane 1-4: Sample of pepper plants; P1: ToMV-infected C. amaranticolor; P2: ToMVinfected pepper

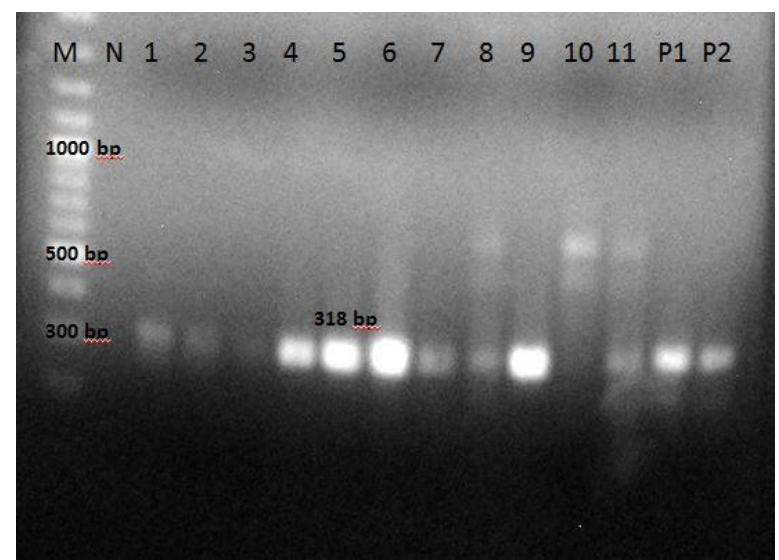

Figure 6. Detection of Tomato mosaic virus by IC-RT-PCR. M: 100 bp DNA ladder; $N$ : healthy pepper. Lane 1-11: Sample of pepper plants; P1: ToMV-infected C. amaranticolor; P2: ToMVinfected pepper

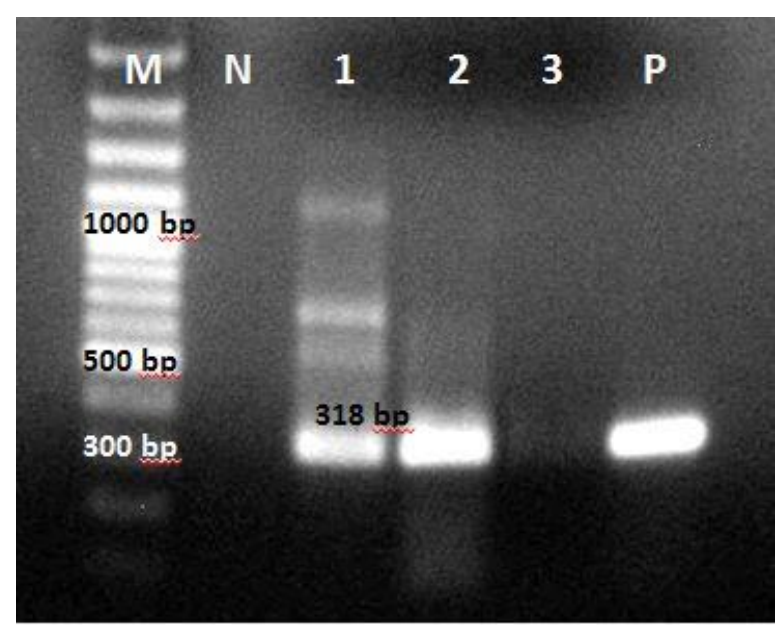

Figure 7. Detection of Tomato mosaic virus by IC-RT-PCR. M: 100 bp DNA ladder; N: healthy pepper. Lane 1-2: Sample of pepper plants; P: ToMV-infected C. amaranticolor; Lane 3: healthy C. amaranticolor 


\section{Discussion}

Virus based diseases are quite significant due to the facts that their control is mostly hard and indeed impossible, that there is no effective chemicals and that the viruses spread far and wide via vector insects.

It is essential to first detected the viruses found in the cultivated culture plant in order to minimize the damages due to viruses and to develop control strategies. The symptomatologic studies that will be carried out based on observation for defining the viruses should be supported with serologic and molecular tests that will be carried out. It is possible to take precautions for the control of this virus disease only after carrying out the diagnosis of this factor. Biological, serological, and molecular assays have generally been used for identification of plant viruses. Although ELISA is preferred assay for routine virus detection, RT-PCR has increasingly been used for detection and identification of viruses due to higher level of sensitivity (Almeida et al., 2018). Among the molecular methods, the most widely used is the RT-PCR (Liu et al., 2014). The ICRT-PCR technique has as an advantage the fact that crushing of the plants for the viral RNA extraction is unnecessary, since only the viral particles that lie on the outside are captured by the specific antiserum (Mulholland, 2009). Another advantage of IC-RTPCR, compared to RT-PCR, would be the speed of testing. The RNA obtained by ICRT-PCR is performed in fewer steps when compared with RT-PCR (Chikh-Ali and Karasev, 2015; Çulal-Kılıç et al., 2017).

The mosaic, contraction in the nervures, spotting, leaf and fruit deformations as well as necrosis formation on the leaves observed during the surveys carried out at Burdur and Denizli pepper cultivation areas were in accordance with the symptoms reported in previous studies mosaic symptoms and stunting symptoms (Kumar et al., 2011; Svoboda and Svobodova-Leisova, 2012).

The symptoms that occur in Capsicum annuum, Chenopodium amaranticolor and Nicotiana glutinosa as a result of mechanical inoculation put forth the existence of ToMV in leaf samples collected. The acquired symptoms were in accordance with previous study results and supports the view that the virus can be ToMV (Aghamohammadi et al., 2013; Ullah et al., 2017).

However, it is a fact that sometimes symptoms cannot be observed in mechanical inoculation method due to various reasons. That is why, detection studies should be supported with more sensitive methods since the use of this method by itself might lead to errors.

The positive reactions acquired during the serologic test carried out to diagnose the virus signify the existence of ToMV in the plant. The ELISA tests used in the diagnosis work for many plant viruses have widely been used by researchers (Geyik, 2017; Kapoor et al., 2018). The fact that it is fast, sensitive, economical and reliable makes this method a preference (Vinayarani et al., 2011; Almeida et al., 2018).

It has been found in this study as a result of carrying out DAS-ELISA tests on the leaf samples that 10 of the 209 samples were infected with ToMV. ToMV infection has been detected in studies carried out at various parts of our country (Gümüş and Paylan, 2013; Özdağ and Sertkaya, 2017).

Özdağ and Sertkaya and (2017) has carried out survey studies to determine the virus diseases in pepper areas in Hatay province and it has been found as a result that of the 303 plant samples, CMV, PLRV, PVX, PVY, PMMoV, PepMoV, ToMV and TSWV. DAS-ELISA method has been used to detect the viruses. 
20 samples that yield absorbance values close to positive and 10 samples that yield positive results DAS-ELISA have been handled in IC-RT-PCR work. In these studies, base pairs that amplify the $318 \mathrm{bp}$ of ToMV and the replicase gene have been used. As a result, expected band was observed in all of the 30 isolates (\%100) which put forth that the samples are infected with ToMV. The results of this study were in accordance with the study by Kumar et al. (2011) carried out using primer pairs designed for ToMV. The same researchers have acquired a 318 bp band in molecular studies. Similarly, Gümüş and Paylan (2013); Almeida et al. (2018) have used IC-RT-PCR method to determine the presence of ToMV in their studies.

10 of the 209 samples used in DAS-ELISA tests were determined to be infected with ToMV, whereas it was determined in IC-RT-PCR studies that all 30 samples (\%100) were infected with ToMV putting forth that PCR method is much more sensitive with respect to ELISA especially when virus density is low. IC-RT-PCR showed greater sensitivity in detecting to ToMV.

According to results of symptom inspections on plants, IC-RT-PCR, DAS-ELISA and mechanical inoculation studies, ToMV in Burdur and Denizli provinces was caused by more than one agent. ToMV was not detected in all the symptomatic samples, it is thought those symptoms were also caused by other viruses. Studies on those potential viruses must be carried out to find out the causal viruse of pepper in this region. 179 pepper samples that showed virus-like symptoms did not react with the antiserum of ToMV used in serological test and IC-RT-PCR method indicating that they were possibly infected with other pepper viruses.

\section{Conclusions}

In this study, the existence of ToMV in the pepper production areas at Burdur and Denizli provinces have been found out using biological, serological and molecular methods. Previous studies also identified TSWV as common virus infecting pepper (Çulal-Kılıç et al., 2017) in same zone. ToMV in peppers in this region were firstly identified in this study.

\section{REFERENCES}

[1] Aghamohammadi, V., Rakhshandehroo, F., Shams-Bakhsh, M., Palukaitis, P. (2013): Distribution and genetic diversity of tomato mosaic virus isolates In Iran. - Plant Pathol J 95(2): 339-347.

[2] Agrios, G. N. (1997): Plant Pathology. - Academic Press Inc., New York.

[3] Almeida, J. E. M., Figueira, A. R., Duarte, P. G., Lucas, M. A., Alencar, N. E. (2018): Procedure for detecting tobamovirus in tomato and pepper seeds decreases the cost analysis. - Bragantia 77(4): 590-598.

[4] Anonymous (2017): http://megep.meb.gov.tr. - Accessed on 25 Oct 2017.

[5] Arogundade, O., Balogun, O. S., Kareem, K. T. (2012): Occurrence and distribution of pepper veinal mottle virus and cucumber mosaic virus in pepper in Ibadan, Nigeria. Virol J 19: 79.

[6] Cherian, S., Muniyappa, N. (1998): ELISA based survey and host range of Tomato mosaic tobamovirus. - Indian J Virol 14: 65-69.

[7] Chikh-Ali, M., Karasev, A. V. (2015): Immunocapture-Multiplex RT-PCR for the Simultaneous Detection and Identification of Plant Viruses and Their Strains: Study Case, 
Potato Virus Y (PVY). - In: Lacomme, C. (ed.) Plant Pathology. Methods in Molecular Biology. Humana Press, New York, pp. 177-186.

[8] Clark, M. F., Adams, A. N. (1977): Characteristics of the microplate method of enzyme linked immunosorbent assay for the detection of plant viruses. - J Gen Virol 34: 475-483.

[9] Çulal Kılıç, H., Yardımcı, N., Bal, A., Güneş, A., Deniz, F. (2017): Sensitive detection of tomato spotted wilt virus from pepper plants by DAS-ELISA, RT-PCR and IC-RT-PCR. - Rom Biotech Lett 22(5): 12934-12939.

[10] FAO (2016): http://faostat.fao.org/site/567/Desktop. - Accessed on 11 Apr 2016.

[11] Geyik, S. (2017): Investigation on tomato virus diseases of virus in tomato growing areas in the Marmara Region of Turkey. - MSc Thesis, Namık Kemal University, Graduate School of Natural and Applied Sciences, Department of Plant Protection.

[12] Gümüş, M., Paylan, I. C. (2013): Detection of viruses in seeds of some vegetables by reverse transcriptase polymerase chain reaction (RT-PCR). - Afr J Biotechnol 12(25): 3891-3897.

[13] Jacobi, V., Bachand, G. D., Hamelin, R. C., Castello, J. D. (1998): Development of multiplex Immunocapture RT-PCR assay for detection and differentiation of tomato and tobacco mosaic viruses. - J Virol Methods 74: 167-178.

[14] Kapoor, S., Sharma, A., Handa, A. 2018. Correlation between symptoms and ELISA for the detection of cucumber mosaic virus in bell pepper. - Int J Curr Microbiol App Sci 7(6): 400-406.

[15] Kenyon, L., Kumar, S., Tsai, W. S., Hughes, J. (2014): Virus diseases of peppers (Capsicum spp.) and their control. - Adv Virus Res 90: 297-354.

[16] Kumar, S., Udaya Shankar, A. C., Nayaka, S. C., Lund, O. S., Prakash, H. S. (2011): Detection of Tobacco mosaic virus and Tomato mosaic virus in pepper and tomato by multiplex RT-PCR. - Lett Appl Microbiol 53: 359-363.

[17] Liu, H. W., Luo, L. X., Li, J. Q., Liu, P. F., Chen, X. Y., Hao, J. J. (2014): Pollen and seed transmission of Cucumber green mottle mosaic virus in cucumber. - Plant Pathol 63: 72-77.

[18] Mulholland, V. (2009): Immunocapture-PCR for Plant Virus Detection. - In: Burns, R. (ed.) Plant Pathology. - Methods in Molecular Biology, Totowa, Humana Press, pp. 183192.

[19] Özdă̆, Y., Sertkaya, G. (2017): Investigation on viruses causing yellowing disease in pepper in Hatay-Turkey. - Journal of Agricultural Faculty of Mustafa Kemal University 22(1): 16-22.

[20] Ryu, J. G., Ko, S. J., Lee, Y. H., Kim, M. K., Kim, K. H., Kim, H. T., Choi, H. S. (2009): Incidence and distribution of virus diseases on paprika (Capsicum annuum var. grossum) in Jeonnam province of Korea. - Plant Pathol J 25(1): 95-98.

[21] Sertkaya, G. (2012): Studies on the Tomato mosaic virus (ToMV on red pepper production areas in Hatay, Turkey. $-9^{\text {th }}$ National Symposium on Vegetable, 12-14 September, Konya.

[22] Silva, P. P., Freitas, R. A., Nascimento, W. M. (2011): Detection of Tomato mosaic virus in tomato seed and treatment by thermotherapy. - Acta Hortic 917: 303-308.

[23] Svoboda, J., Svobodová-Leišová, L. (2012): Occurrence of viruses on pepper plantations in the Czech Republic. - Hortic Sci 39(3): 139-143.

[24] Şevik, M. A. (2011): Occurence of pepper mild mottle virus in greenhouse grown pepper (Capsicum annuum L.) in the West Mediterranean region of Turkey. - Afr J Biotechnol 10(25): 4976-4979.

[25] Şevik, M. A. (2016): Turnip mosaic virus infecting kale plants in Ordu, Turkey. - Phyton Int J Exp Bot 85: 231-235.

[26] Tuik (2016). Crop Production Statistics. Turkish Statistical Institute. Turkey. http://tuikrapor.tuik.gov.tr/reports. Accessed on 04 May 2016. 
[27] Ullah, N., Ali, A., Ahmad, M., Fahim, M., Din, N., Ahmed, F. (2017): Evaluation of tomato genotyper against tomato mosaic virus (ToMV) and its effect on yield contributing parameters. - Pak J Bot 49(4): 1585-1592.

[28] Vinayarani, G., Madhusudhan, K. N., Deepak, S. A., Niranjand, S. R., Prakash, H. S. (2011): Detection of mixed infection of tobamoviruses in tomato and bell pepper by using RT-PCR and duplex RTR-PCR. - Int J Plant Pathol 2(2): 89-95. 